\title{
Sipunculan fauna in the Pacific Arctic region: a significant component of benthic infaunal communities
}

\author{
Monika Kędra $^{1}$ - Jacqueline M. Grebmeier ${ }^{2}$ Lee W. Cooper ${ }^{2}$
}

Received: 14 February 2017/Revised: 11 July 2017/ Accepted: 11 July 2017 / Published online: 31 July 2017

(C) The Author(s) 2017. This article is an open access publication

\begin{abstract}
The Sipuncula show low species diversity in the Arctic Ocean, but they often occur in very high numbers and biomass, and can dominate shelf benthic communities. We describe here the patterns of sipunculan diversity, abundance, biomass, and species distribution in the Pacific Arctic, and the relation of those patterns to controlling environmental factors. Five species (including two subspecies) belonging to two families and three genera are known to be present in Pacific-influenced Arctic waters. Although sipunculans were found at only about $30 \%$ of sampled stations, they constituted, if present, up to about $10 \%$ of the total macrobenthic abundance, and over $80 \%$ of the total infaunal biomass, particularly in many locations in the Chukchi Sea. The mean sipunculan abundance was $24.5 \pm 155.9$ individuals $\mathrm{m}^{-2}$, with a maximum of 1745 individuals $\mathrm{m}^{-2}$. The mean sipunculan biomass was $14.0 \pm 73.8 \mathrm{~g}$ wet weight $\mathrm{m}^{-2}$, with a maximum of $698.7 \mathrm{~g}$ wet weight $\mathrm{m}^{-2}$ in the northwest Chukchi Sea. The sipunculan abundances and biomass observed were related to latitude, depth, and sediment characteristics. The populations observed should be considered significant and characteristic components of the Pacific Arctic shallow shelf systems and food webs. This conclusion proves to be true also for other Arctic shelf seas like the Barents Sea, and deep Arctic ecosystems.
\end{abstract}

Monika Kędra

kedra@iopan.gda.pl

1 Institute of Oceanology Polish Academy of Sciences, Powstańców Warszawy 55, 81-712 Sopot, Poland

2 Chesapeake Biological Laboratory, University of Maryland Center for Environmental Science, Solomons 20688, MD, USA
Keywords Sipuncula - Benthos - Pacific Arctic region . Diversity · Distribution · Food web

\section{Introduction}

The Sipuncula is a small and species-poor phylum of about 150 species widely distributed in the world's oceans in all depths (Cutler 1994). In the Arctic seas there are only about 12 species (Murina 1977; Kędra and Murina 2007), but, despite low diversity, they often occur in very high numbers and biomass, dominating benthic communities in both shelf and deep-sea habitats (Grebmeier et al. 2006, 2015; Kędra and Włodarska-Kowalczuk 2008; Shields and Kędra 2009). Sipunculans are active burrowers and important bioturbators (Murina 1984). In the deep sea they are known as 'ecosystem engineers' and producers of deep burrows (genus Nephasoma; Romero-Wetzel 1987; Graf 1989). They are mainly deposit feeders, and usually transform particulate organic matter (microalgae, protista, meiofauna, detritus, fecal pellets) from the water column, sediment surface or sediment itself (Murina 1984), but some species may also filter-feed (Gibbs 1977). In turn, sipunculans are preyed upon by cephalopods, sea anemones, crabs (Fischer 1925; Divine et al. 2017), gastropods and fish (Kohn 1975), and marine mammals, such as walruses (Sheffield et al. 2001; Sheffield and Grebmeier 2009).

Most studies of sipunculans in the Arctic have been predominantly concentrated in the Atlantic sector of the Arctic: Greenland (Wesenberg-Lund 1934, 1937, 1938), Svalbard (Kędra and Murina 2007), and the deep Nordic Seas (Kędra and Shields 2011). The Pacific Arctic Region has received much less scientific attention in terms of sipunculan fauna (Murina 1977, 1985; Kędra and 
Grebmeier in press). Murina (1977) is the lone monograph summarizing the state of knowledge on sipunculans in all Arctic seas. These earlier studies, however, focused on taxonomic aspects, while the ecological role and function, especially in the food web, have only rarely been studied in the Arctic Ocean. The few exceptions include studies in the Barents Sea (Garbul and Anisimova 2012), Svalbard fjords (Kędra and Włodarska-Kowalczuk 2008), and deep Nordic Seas (Shields and Kędra 2009). However, to the best of our knowledge, a synopsis of the ecology of the group in the Pacific Arctic waters has never been attempted. Yet, sipunculans are known to dominate the benthic biomass and abundance in various regions in the Pacific Arctic, especially in the northern Chukchi Sea (e.g., Grebmeier et al. 2006, 2015).

Here, we put together extensive data on the sipunculan distribution, diversity, abundance, and biomass in the waters of the northern Bering and Chukchi Seas. Additional qualitative data from the Beaufort Sea are also presented. The aim of the present study is to: (1) describe the patterns of sipunculan diversity, abundance, biomass, and species distribution in the Pacific Arctic, (2) relate observed patterns to environmental factors, and (3) discuss the role of sipunculans in functioning of the Pacific Arctic shallow shelf ecosystems.

\section{Materials and methods}

\section{Study area}

The Pacific Arctic marine ecosystem consists of the broadshallow continental shelves of the northern Bering, the Chukchi and eastern East Siberian seas, and the narrow shelf and steep slope of the Beaufort Sea. The region is seasonally ice-covered and sea ice extent usually reaches a maximum in March and a minimum in September. The water masses of Pacific origin flowing northwards toward the Arctic Basin include: the narrow, surface-intensified, nutrient-poor, warm, and fresher $(<31.8)$ Alaska Coastal Water (ACW) along the Alaskan coast, the nutrient-rich and more saline (>32.5) Anadyr Water (AW) near the Siberian coast, and the moderately warm, intermediate saline (31.8-32.5) Bering Shelf Water (BSW) in between (Coachman et al. 1975; Woodgate et al. 2005a, b; Grebmeier et al. 2006). Nutrients and algal production, organic carbon, zooplankton, and hydrographic properties are redistributed by these water masses from the Bering slope and the central Bering shelf into the northern Bering and Chukchi seas, and further into the Arctic Ocean (Walsh et al. 1989; Weingartner et al. 2005; Woodgate et al. 2012; Grebmeier et al. 2015; Lowry et al. 2015). The hydrography of these water masses controls the intensity of primary production in the region (Walsh et al. 1989). The northern Bering and Chukchi Seas are highly productive during iceedge retreat (Hill and Cota 2005; Hill et al. 2017), but studies indicate declining production in the northern Bering Sea over the recent years (Lee et al. 2012). By contrast, primary production is low in the coastal waters of the Chukchi Sea and in the East Siberian Sea, but it may be increasing in offshore waters over recent years (Sakshaug 2004; Hirawake et al. 2012; Petrenko et al. 2013). Production is also low in the western Beaufort Sea, with some exceptions, such as in upwelling-induced algal blooms at the outer shelf/upper slope region (Cooper et al. 2005; Tremblay et al. 2011). In these shallow shelf areas, much of the organic matter that is formed in surface shelf waters is either exported unconsumed to the seafloor and fuels productive benthic communities (Ambrose et al. 2005; Grebmeier et al. 2006, 2015; Grebmeier 2012), or, having reached the shelf break, it is transported into the basin (Bates et al. 2005; Moran et al. 2005). Mud and muddy sands dominate in offshore sediments in the northern Bering, Chukchi, and East Siberian Seas, while finer silts and clays occur in the slope and basin regions (Grebmeier et al. 2006; Grebmeier and Cooper 2014a; Pisareva et al. 2015). High current regimes promote the dominance of gravel, pebbles, rocks, and sand close to St. Lawrence Island, in nearshore regions of the Chirikov Basin, Bering Strait, Herald Valley, west of Wrangel Island, and near the Alaskan coast. The total organic carbon (TOC) content in the surface sediments is positively correlated with silt and clay content, and is high in deposition areas (Grebmeier and Cooper 1994; Grebmeier et al. 2006). Due to the tight pelagic-benthic coupling, the biomass of benthic fauna is high and is preyed upon by seabirds and marine mammals (Grebmeier et al. 2006; Sheffield and Grebmeier 2009).

\section{Sampling}

Sipunculan samples were collected during 9 cruises in the northern Bering and Chukchi Seas from 2007 to 2012, along with additional four cruises to the Beaufort Sea from 2013 to 2015. Altogether 277 stations were sampled quantitatively, with van Veen grabs $\left(0.1 \mathrm{~m}^{2}\right.$ catch area; four replicates per station, with a few exceptions-single grabs were taken during SHELL09 and SHELL10 cruises in the Chukchi Sea) from $61^{\circ} 18^{\prime} \mathrm{N}$, north to $76^{\circ} 36^{\prime} \mathrm{N}$ in the northern Bering Sea and Chukchi Seas. Additional 19 stations were sampled qualitatively in the Beaufort Sea with a benthic trawl [modified 3-m plumb-staff beam trawl (PSBT-A)] (Fig. 1). The sampling effort is summarized in Table 1 . The sediment retrieved by the sampling gear was washed on a 1-mm sieve and fixed in a $10 \%$ buffered formaldehyde and seawater solution. The organisms were picked out, counted, and weighed after blotting. Sipunculan 


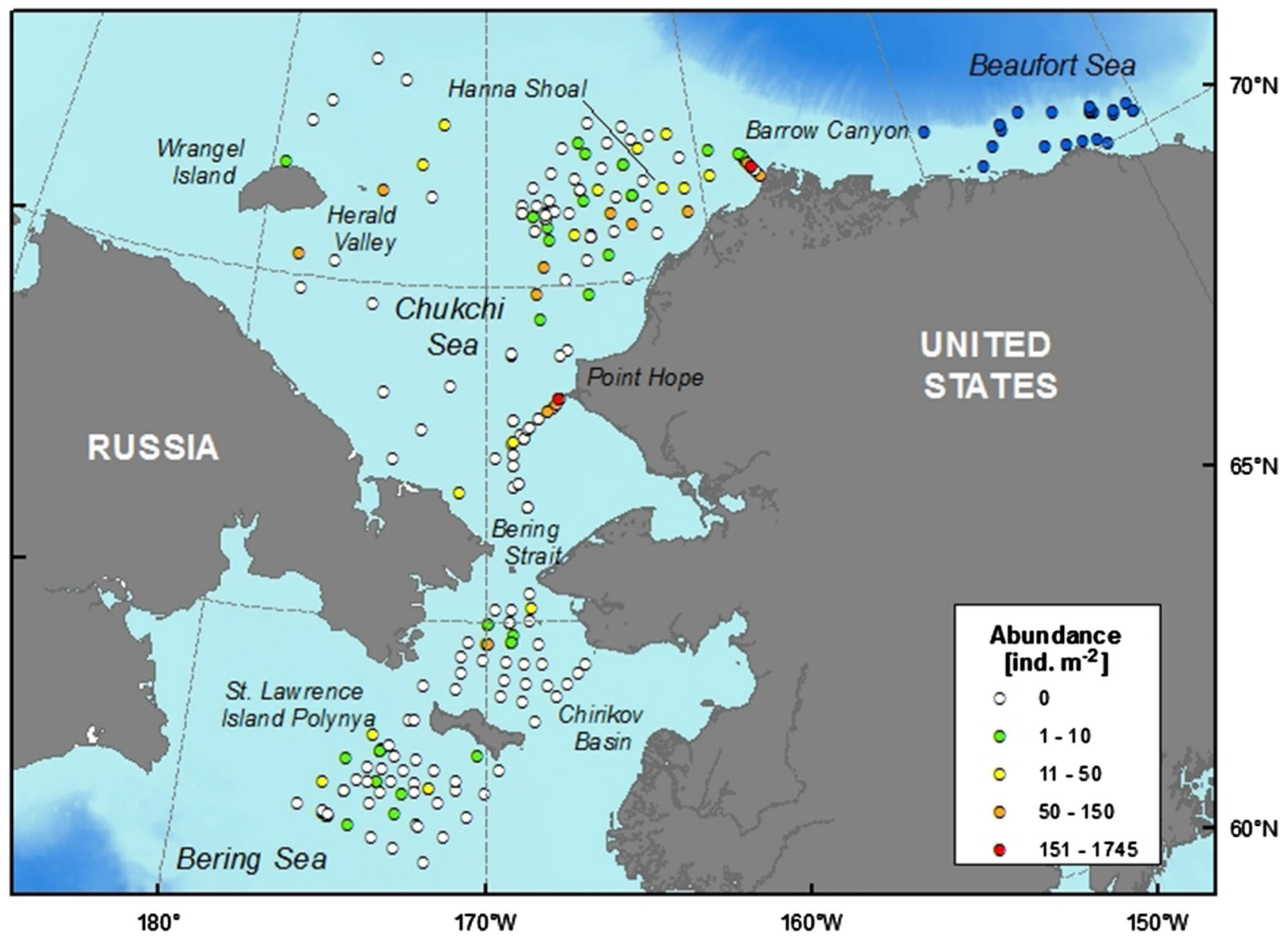

Fig. 1 Location of sampling stations in St. Lawrence Island Polynya, Chirikov Basin and Chukchi Sea (quantitative sampling), and Beaufort Sea (qualitative sampling - in blue). Sipunculan abundance (ind. $\mathrm{m}^{-2}$ ) is given only for quantitative sampling

specimens were identified to the species level, counted, and weighed. The worms were post-fixed with $50 \%$ propanol. Sipunculans from the Beaufort Sea samples were identified, counted, and fixed following the same procedure. Altogether, over 1100 samples were analyzed and 2370 sipunculan specimens were found and identified. All taxonomic nomenclature used follows that of Cutler (1994). The specimens examined are archived at the Chesapeake Biological Laboratory University of Maryland Center for Environmental Science (Solomons, Maryland, USA; specimens from the Bering and Chukchi Seas) and Institute of Oceanology Polish Academy of Sciences (Sopot, Poland; specimens from the Beaufort Sea).

\section{Analysis}

In order to determine which environmental factors [depth, bottom temperature, bottom salinity, sediment chlorophyll (chl) $a$, total organic carbon, total organic nitrogen, $\mathrm{C} / \mathrm{N}$, sediment type (gravel, coarse, medium, fine, and very fine sands, and muds), latitude and longitude as proxy for sea ice cover and distance to the coast] explained most variability among stations (quantitative sampling) we performed principal component analysis (PCA, Primer, http:// www.primer-e.com) on normalized data. On the basis of the PCA plot we selected 6 sampling groups that were determined by the combination of grain size [mud-with dominance of $\geq 5$ phi fraction, sand-with dominance of combined 1-4 phi fraction, and stations where gravel fraction ( $\leq 0 \mathrm{phi}$ ) had significant (at least $20 \%$ ) contribution] and sampling region. Differences among those groups were tested with the ANOSIM test. Proportional densities of two dominant species (Golfingia margaritacea, Phascolion strombus) were plotted on the PCA plot. Data were not normally distributed and normality could not be obtained after data transformation (Shapiro-Wilk test, $W=0.17, \quad p=0.0001$ for sipunculan abundance, $W=0.25, p=0.0001$ for sipunculan biomass). Mean 
Table 1 Sampling effort and basic information on samples used in the present study

\begin{tabular}{|c|c|c|c|c|c|c|}
\hline Cruise and acronym & $\begin{array}{l}\text { Sampling } \\
\text { months and } \\
\text { years }\end{array}$ & $\begin{array}{l}\text { Sampling } \\
\text { gear type }\end{array}$ & $\begin{array}{l}\text { Depths of } \\
\text { sampling } \\
\text { (m) }\end{array}$ & $\begin{array}{l}\text { Number of } \\
\text { stations } \\
\text { sampled }\end{array}$ & $\begin{array}{l}\text { Number of } \\
\text { stations with } \\
\text { sipunculans }\end{array}$ & Reference \\
\hline USCGC Healy (HLY0702) & $\begin{array}{l}\text { May/June } \\
2007\end{array}$ & VV & $27-96$ & 72 & $13(18 \%)$ & $\begin{array}{l}\text { Grebmeier and Cooper } \\
(2014 b, c, 2016)\end{array}$ \\
\hline \multirow{2}{*}{$\begin{array}{l}\text { Chukchi Sea Offshore Monitoring in } \\
\text { Drilling Area (COMIDA09, } \\
\text { COMIDA10) }\end{array}$} & \multirow{2}{*}{$\begin{array}{l}\text { July/August } \\
2009,2010\end{array}$} & \multirow[t]{2}{*}{ VV } & $28-130$ & 30 & $12(40 \%)$ & \multirow{2}{*}{$\begin{array}{l}\text { Grebmeier and Cooper } \\
(2014 b, c), \text { Dunton } \\
\text { et al. }(2016)\end{array}$} \\
\hline & & & $30-130$ & 21 & $14(66 \%)$ & \\
\hline \multirow{2}{*}{$\begin{array}{l}\text { SHELL09, SHELL10 (SHELL Oil } \\
\text { funded studies within COMIDA CAB } \\
\text { project) }\end{array}$} & \multirow{2}{*}{$\begin{array}{l}\text { August } \\
2009,2010\end{array}$} & VV & $43-48$ & 33 & $11(33 \%)$ & \multirow{2}{*}{$\begin{array}{l}\text { Grebmeier and Cooper } \\
(2014 b, c)\end{array}$} \\
\hline & & VV & $46-58$ & 35 & $4(11 \%)$ & \\
\hline \multirow{3}{*}{$\begin{array}{l}\text { CCGS Sir Wilfrid Laurier (SWL10, } \\
\text { SWL11, SWL12) }\end{array}$} & \multirow{3}{*}{$\begin{array}{l}\text { July } 2010, \\
2011,2012\end{array}$} & VV & $35-86$ & 16 & $6(37 \%)$ & \multirow{3}{*}{$\begin{array}{l}\text { Grebmeier and Cooper } \\
(2014 b, c)\end{array}$} \\
\hline & & VV & $34-126$ & 33 & $21(63 \%)$ & \\
\hline & & VV & $34-81$ & 19 & $9(47 \%)$ & \\
\hline $\begin{array}{l}\text { Russian-American Long-term census of } \\
\text { the Arctic (RUSALCA2009) }\end{array}$ & $\begin{array}{l}\text { September } \\
2009\end{array}$ & VV & 29-604 & 23 & $8(35 \%)$ & $\begin{array}{l}\text { Crane and Ostrovskiy } \\
\text { (2015), Grebmeier } \\
\text { et al. (2015) }\end{array}$ \\
\hline \multirow[t]{2}{*}{ Transboundary (ТВ2013, ТВ2014) } & \multirow{2}{*}{$\begin{array}{l}\text { August/ } \\
\text { September } \\
2013,2014\end{array}$} & PSBT-A & $50-500$ & - & 7 & Norcross et al. (2016) \\
\hline & & PSBT-A & $200-753$ & - & 8 & Norcross et al. (2016) \\
\hline \multirow{2}{*}{$\begin{array}{l}\text { Arctic Nearshore impact monitoring in } \\
\text { development area (ANIMIDA2014, } \\
\text { ANIMIDA2015) }\end{array}$} & \multirow{2}{*}{$\begin{array}{l}\text { August } \\
2014,2015\end{array}$} & PSBT-A & $36-200$ & - & 3 & \multirow{2}{*}{$\begin{array}{l}\text { Olgoonik Fairweather } \\
\text { LLC (2017) }\end{array}$} \\
\hline & & PSBT-A & $19-40$ & - & 5 & \\
\hline
\end{tabular}

The table includes references to original studies. Sampling type: $V V 0.1 \mathrm{~m}^{2}$ van Veen grab, $P S B T-A$ modified 3-m plumb-staff beam trawl

values of the abundance and biomass with standard deviations (SD) were calculated within groups of quantitative samples collected from three areas: the St. Lawrence Island Polynya (SLIP), the Chirikov Basin (ChB), and the Chukchi Sea (CS), separated on the bases of sediment type. In addition, extreme values (larger than 3 times the range of standard error) were calculated. The environment-species relations were explored with the canonical corresponded analysis (CCA), which was determined to be appropriate by the results of a preliminary de-trended correspondence analysis (DCA) using the length of the main gradient (after ter Braak and Smilauer 2002). The forward selection of environmental variables was used to identify and rank their importance in determining the species distribution (after ter Braak and Smilauer 2002). A subset of best-fitted variables was selected via repeated forward selection analyses and the progressive elimination of variables with non-significant conditional effects was performed until a set of variables with only significant effects was attained. The significance of the ordination axis in CCA and the effects of environmental variables were tested by Monte Carlo permutation tests using 4999 unrestricted permutations. Data analyses were undertaken using Statsoft software STATISTICA v.9 and CANOCO 4.5 (ter Braak and Smilauer 2002).

\section{Results}

Sipunculans were found at 92 of 277 (33\%) stations sampled in the northern Bering and Chukchi Seas, where 2215 sipunculan specimens were collected via quantitative sampling with van Veen grabs (Fig. 1; Table 1). Additionally, 107 specimens were collected by qualitative sampling in the Beaufort Sea using trawls (Fig. 1; Table 1). Five species (including two subspecies) belonging to two families and three genera were found (Table 2). Golfingia margaritacea was the dominant species and constituted $73 \%$ of all specimens sampled, followed by $P$. strombus which constituted $20 \%$. Those were also the only two species found in the Beaufort Sea (Table 2). The PCA showed that selected environmental factors explained $40.8 \%$ of variability among the sampling stations: the first axis explained $24.1 \%$ and the second axis $16.7 \%$ (Fig. 2A). The most important variable that explained first axis variation was the presence of mud (PCA coefficient: 0.5), fine sands $(-0.4)$, and TOC (0.4), and for the second axis: latitude $(-0.4)$ and presence of very fine sand $(0.4)$ and gravel (-0.4). Six groups, determined on the basis of the PCA plot and combination of sediment properties and area sampled, were significantly different from each other (ANOSIM test, $R=0.5, \quad p=0.001 ;$ Fig. 2a). The 
Table 2 Number of sipunculan species and specimens found in this study with basic information on the species

\begin{tabular}{|c|c|c|c|c|c|c|c|}
\hline Species & $\begin{array}{l}\text { Number } \\
\text { of } \\
\text { specimens } \\
\text { found }\end{array}$ & $\begin{array}{l}\% \text { of all } \\
\text { specimens } \\
\text { found }\end{array}$ & $\begin{array}{l}\text { Depths of } \\
\text { occurrence- } \\
\text { current } \\
\text { study }(\mathrm{m})\end{array}$ & $\begin{array}{l}\text { Depths } \\
\text { of } \\
\text { occurrence } \\
\text { in the } \\
\text { World } \\
\text { Ocean (m) }\end{array}$ & Feeding & $\begin{array}{l}\text { Common } \\
\text { (maximum) } \\
\text { trunk } \\
\text { length } \\
(\mathrm{mm})\end{array}$ & Habitat \\
\hline \multicolumn{8}{|l|}{ Golfingiidae } \\
\hline $\begin{array}{l}\text { Golfingia } \\
\quad \text { margaritacea }\end{array}$ & $1621(2)^{\mathrm{a}}$ & 73 & $\begin{array}{l}29-130 \\
(19-40)^{\mathrm{a}}\end{array}$ & $0-5300$ & Deposit feeder & $\begin{array}{r}10-30 \\
(150)\end{array}$ & Sand, mud \\
\hline Golfingia vulgaris & 18 & 1 & $43-130$ & $5-2000$ & Deposit feeder & $\begin{array}{r}10-50 \\
(200)\end{array}$ & Sand, mud, silt, clay \\
\hline $\begin{array}{l}\text { Nephasoma diaphanes } \\
\text { corrugatum }\end{array}$ & 64 & 3 & $49-130$ & $80-5900$ & Deposit feeder & $\begin{array}{l}5-10 \\
(20-30)\end{array}$ & $\begin{array}{l}\text { Mud, sandy silt, } \\
\text { clay, }\end{array}$ \\
\hline $\begin{array}{l}\text { Nephasoma diaphanes } \\
\text { diaphanes }\end{array}$ & 71 & 3 & $38-130$ & $0-5300$ & Deposit feeder & $5(55)$ & Sand, mud, silt, clay \\
\hline Nephasoma eremita & 2 & $<1$ & $64-130$ & $0-3867$ & Deposit feeder & $10-30$ & Sand, mud, clay \\
\hline \multicolumn{8}{|l|}{ Phascolionidae } \\
\hline Phascolion strombus & $\begin{array}{l}439 \\
(153)^{\mathrm{a}}\end{array}$ & 20 & $\begin{array}{l}34-130 \\
(35-753)^{\mathrm{a}}\end{array}$ & $1-4030$ & Deposit feeder & $\begin{array}{l}5-15 \\
\quad(30-40)\end{array}$ & $\begin{array}{l}\text { Sand, mud, silt, } \\
\text { often in } \\
\text { mollusk shells and } \\
\text { polychaete tubes }\end{array}$ \\
\hline Total & 2215 & & & & & & \\
\hline
\end{tabular}

All numbers are given for quantitative sampling in the northern Bering and Chukchi Seas, numbers in parentheses ()

a Correspond to data for species collected in qualitative sampling in the Beaufort Sea

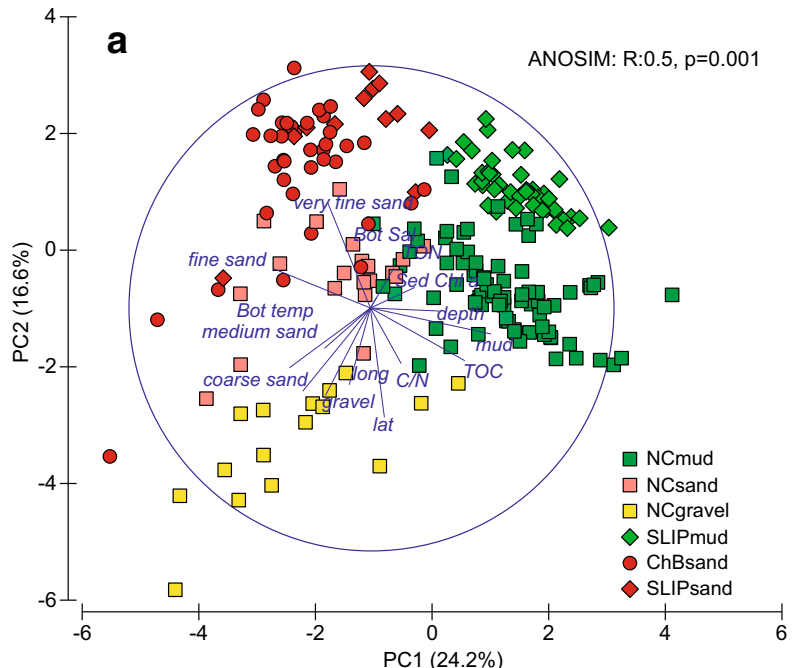

Fig. 2 Principal component analysis of environmental factors for stations within 3 regions: a St. Lawrence Island Polynya (SLIP), Chirikov Basin (ChB), and Chukchi Sea (CS) and different type of sediment (mud-green, sand-red, at least $20 \%$ of gravel contribution-yellow). The two first axes account for $40.8 \%$ of the variation

proportional abundance of two dominant species: G. margaritacea and $P$. strombus were plotted on the PCA showing that the G. margaritacea's abundance increased with increasing proportion of mud in sediments, while $P$.

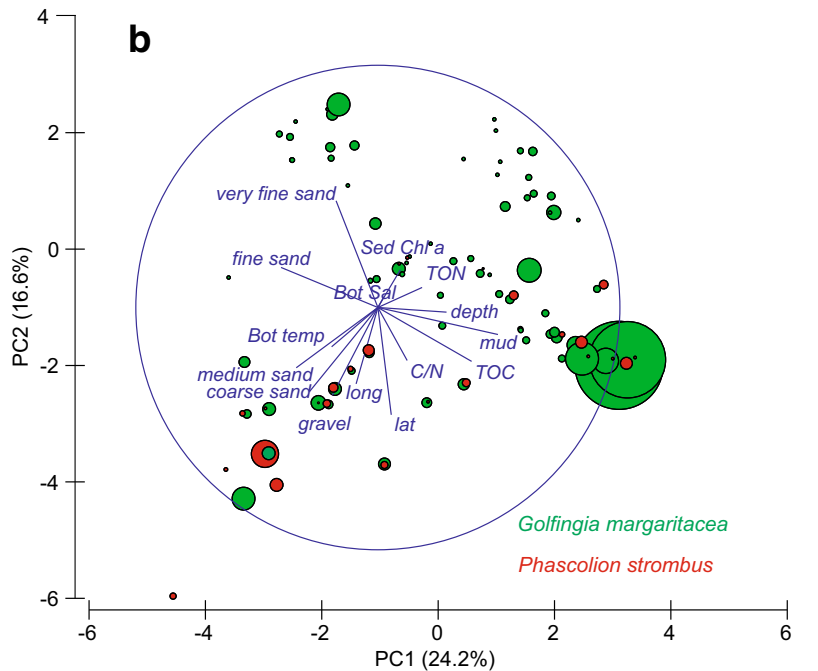

separating stations and results of the ANOSIM test are given. b Plot showing relative abundance of Golfingia margaritacea (green) and Phascolion strombus (red) at sampled stations. The size of the bubbles symbol is proportional to sipunculan mean abundance

strombus tended to occur in higher densities where sediments were coarser (Fig. 2b). The overall mean sipunculan abundance (based upon quantitative sampling, including samples where sipunculans were not found) was 
$24.5 \pm 155.9$ ind. $\mathrm{m}^{-2} \mathrm{SD}$ (standard deviation) and ranged, where sipunculans were sampled, from 10 to 1745 ind. $\mathrm{m}^{-2}$. The values tended to increase with latitude, were higher on muddy sediments, and where gravel fraction was present, and were the highest in the Chukchi Sea, particularly in the Barrow Canyon, near Point Hope, and Hanna Shoal (Figs. 3a, 4a). The mean sipunculan biomass was $14.0 \pm 73.8 \mathrm{gww} \mathrm{m}^{-2} \mathrm{SD}$ and, when present, ranged from 0.005 to $698.7 \mathrm{gww} \mathrm{m}^{-2}$. The lowest values were observed in sandy sediments, while the highest values were in muds, and gravely sediment in the Barrow Canyon and Hanna Shoal (Figs. 3b, 4b). In the northern Bering and Chukchi Seas sipunculans constituted up to $12 \%$ of the total macrobenthic abundance and the proportion increased northwards, and up to $86 \%$ of the total infaunal biomass, with the highest proportions in the northern Chukchi Sea (Fig. 4a, b). The largest specimens belonged to species $G$. margaritacea, often strongly inflating the total faunal biomass that would otherwise be present without sipunculans. High proportion of sipunculans within the total station benthic biomass was due to G. margaritacea, while high proportion of sipunculans in the total benthic abundance was either due to the presence of G. margaritacea or $P$. strombus; however, although the two species often cooccurred, their highest abundances were associated with different stations with different environmental settings (Fig. 2b).

Sipunculans were found at all the depths sampled (from 20 to $750 \mathrm{~m}$ ) and in all areas-but not at all locations (Figs. 1, 2; Table 1). Sipunculans seem to avoid sediments with higher proportion of medium and coarse sands (Fig. 2b). The CCA analysis explained about $30 \%$ of the variance of the species-environment relationship (Fig. 5). The first canonical axis was significant (Monte Carlo test, $F=20.234, p=0.0132$ ) and so were all canonical axes $(F=3.046, p=0.0124)$. The first axis explained $19.2 \%$ of

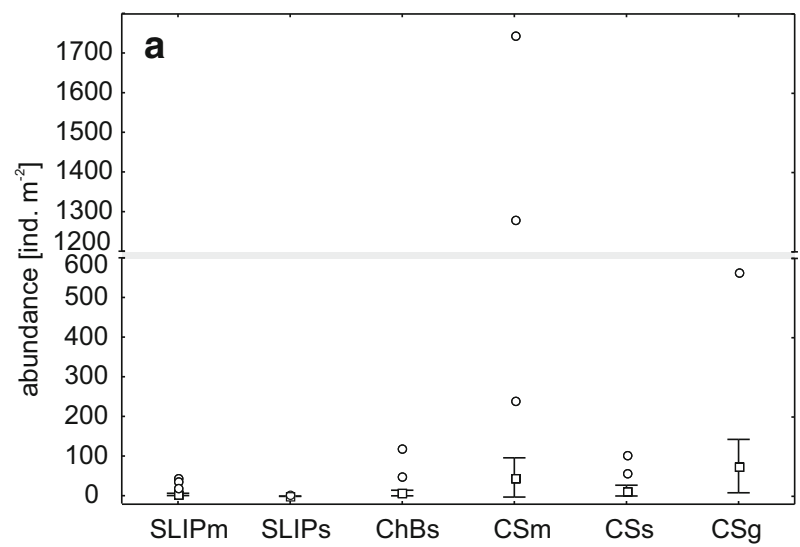

Fig. 3 Basic statistics (mean with 0.95 confidence intervals) for abundance (a) and biomass (b) of sipunculan fauna in: St. Lawrence Island Polynya (SLIP), Chirikov Basin (ChB), and Chukchi Sea (CS) variance, while the second axis explained $7.1 \%$. The occurrence of gravel and coarse sand fractions were positively correlated with the first axis $(0.76$ and 0.61 respectively), while presence of mud fraction was negatively correlated $(-0.59)$. The latitude, $\mathrm{C} / \mathrm{N}$, TOC, and depth correlated with the second axis $(0.46,0.36,0.35$, and 0.34 , respectively) and presence of very fine sand was negatively correlated $(-0.37)$. Three variables were selected as significant predictors of sipunculan species distribution by the forward selection analyses: the occurrence of gravel (Monte Carlo test, $F=18.89, \quad p=0.002$ ), depth $(F=6.91, p=0.002)$, and latitudinal position $(F=3.91$, $p=0.008$ ). The presence of gravel explained about $16.3 \%$ of the variance of the species-environment relationship, latitude-next $5.6 \%$, and depth-3\%. The P. strombus occurrence was correlated with the percentage of a coarser grain size (gravel, coarse sand) in the sediment, the occurrence of Nephasoma diaphanes was correlated with the percentage of fine and very fine sand, while the abundance of $G$. margaritacea increased weakly along gradients of increasing depth, TOC, and mud fraction (Fig. 5). Nephasoma eremita was very rarely found and occurred only in the northernmost locations (Table 1).

\section{Discussion}

The northern Bering and Chukchi Seas are among the most productive soft-bottom marine ecosystems in the world, with very high benthic biomass, to which sipunculans, in many areas, contribute markedly (Grebmeier et al. 2006, 2015; this study). Golfingia margaritacea is the sipunculan that contributes most to high benthic biomass at specific sites due to its large size and high individual biomass (Kędra and Włodarska-Kowalczuk 2008), although the less abundant species Golfingia vulgaris can also reach

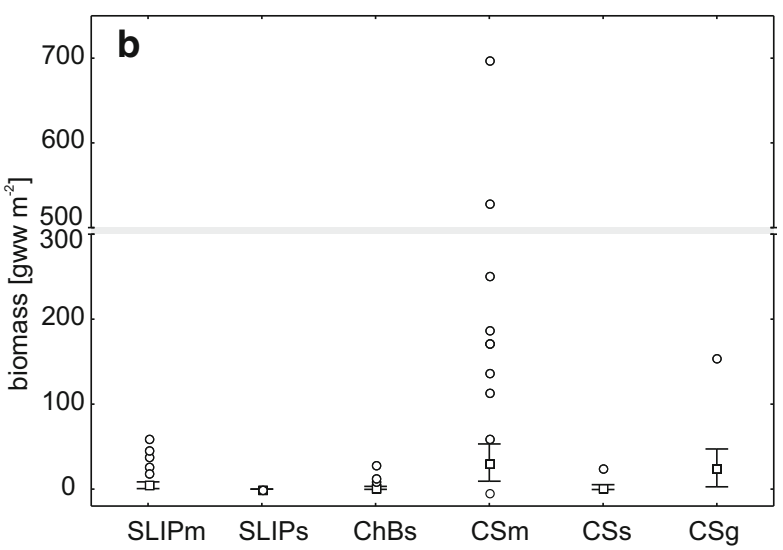

in three different sediment types: muds (m), sands (s), and with at least $20 \%$ of gravel contribution $(\mathrm{g})$. Extreme values equal or exceeding three ranges of standard deviations are marked 

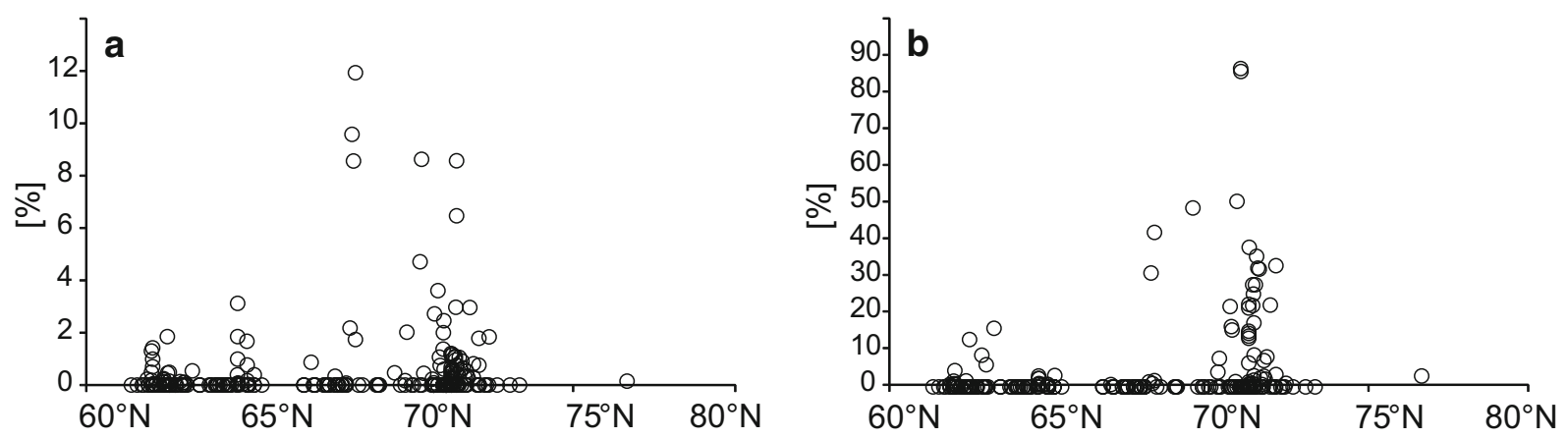

Fig. 4 Percentages of the sipunculan fauna contribution to the total benthic abundance (a) and biomass (b) of sipunculans in relation to the latitudinal gradient

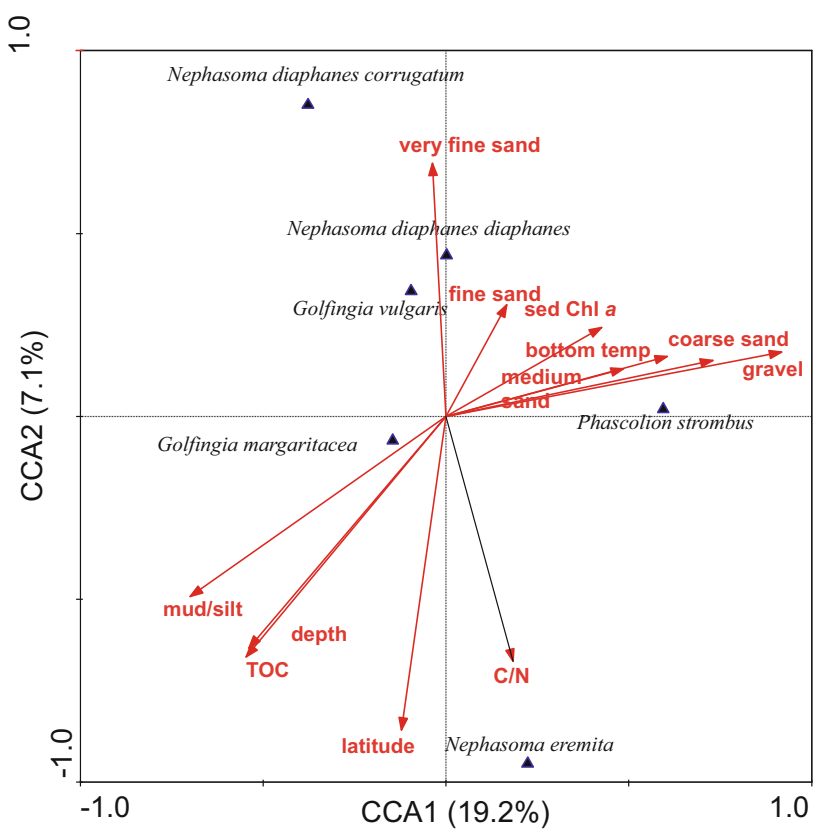

Fig. 5 Ordination diagram based on the canonical correspondence analyses (CCA) of sipunculan species occurrence with respect to environmental variables. Arrows represent linear variables and triangles are species. First axis explains $19.2 \%$ of the variance, and second axis-7.1\%

large size and high biomass (Garbul and Anisimova 2012; Kędra and Grebmeier in press). Golfingia margaritacea also often occurs in high densities which is further translated to high local biomass. Organisms in this genus are active burrowers and deposit feeders (Grall et al. 2006; McMahon et al. 2006) that indiscriminately ingest the substratum (Murina 1984) and later extract organic matter from the ingested material (Stephen and Edmonds 1972). Golfingia's body can reach over $10 \mathrm{~cm}$ of trunk lengthusually buried in the sediment, and several more $\mathrm{cm}$ of body length (introvert) can be extended outside the burrow while it searches for food on the sediment, often leaving starlike traces (Walter 1973). Golfingia vulgaris has been described as being able to selectively collect food in sediments with small sediment grain sizes (Hansen 1978). Thus, Golfingia species are likely to take advantage of high detritus loads in the sediments resulting from high deposition rates of organic particles. In this study we have shown that the abundance and biomass of sipunculans is correlated with TOC (e.g., the amount of detritus) in the sediments but not with the $\mathrm{C} / \mathrm{N}$ ratio or the inventory of $\mathrm{Chl}$ $a$ in the surface sediments, which are both means of quantifying the food quality of the settling organic matter. High deposition often is related to the weakening of currents, which commonly occurs in shallow areas of the Chukchi Sea north of the Bering Strait and other locations where currents slow down as shelves become less constrained (Pisareva et al. 2015). The sipunculan biomass was particularly high in the deposition areas, such as the southeastern side of Hanna Shoal and the southern Chukchi Sea, and was also high in the western region of St. Lawrence Island Polynya region, the northern portion of Chirikov Basin, and in the center of Barrow Canyon. In all these regions the high primary production rapidly settles to the seafloor and fuels high benthic biomass and rich benthic communities (Dunton et al. 1989; Grebmeier and McRoy 1989; Grebmeier et al. 2006, 2015; Iken et al. 2010).

A similarly high sipunculan biomass is observed in the submarine canyons (Barrow Canyon, Herald Canyon) and close to the Alaskan coast (near Point Hope), where, on the other hand, fast currents are observed (Grebmeier et al. 2006; Pisareva et al. 2015). Golfingia margaritacea is the main contributor to the high biomass in those areas, but here, P. strombus, a species smaller than Golfingia, also often occurred with the highest densities in the southwestern (Russian coast) and southeastern (Alaskan coast) Chukchi Sea and Barrow Canyon. Phascolion strombus is a semimobile, mostly epibenthic worm often living in empty shells and tubes, and collecting sediments with their tentacles (Hylleberg 1975). The ability to seek and find shelter in tubes and shells may help Phascolion's survival in areas with fast currents. Moreover, sipunculans, including 
Golfingia and P. strombus, can switch to filter feeding (Gibbs 1977), which may explain their high abundance (but lower biomass) in areas where suspension feeders dominate as they take advantage of the high flow in those locations (Pisareva et al. 2015). However, deposit feeding is the main feeding type of all sipunculans in the Pacific Arctic, and thus sipunculans, although abundant in habitats under fast currents, do not reach such high biomass as that of in the areas of high deposition. Furthermore, the benthos in areas influenced by the swift ACW, particularly along the Alaskan coast, is mainly dominated by large epifaunal suspension feeders like sea anemones, corals, and ascidians, which successfully compete with infaunal organisms. Such patterns are also observed along the path of the ACW into the Barrow Canyon and in the Canyon itself.

Another important environmental factor shaping sipunculan communities is the sediment type, which is also often significantly correlated with the TOC content (Grebmeier et al. 2006). As already noted by other authors (Table 2), sipunculans (the family Golfingiidae) prefer muddy sediments (Hylleberg 1975), where they can actively burrow and feed on the organic matter on and within the sediment. In our study, G. margaritacea dominated in deposition zones with small grain sized sediments, especially silt/clay. On the other hand, P. strombus is often found in coarser sediments, e.g., sand and gravel (Hylleberg 1975), and in this study were mainly found along the Alaska and Russian coasts and under the strong flow of ACW into the Barrow Canyon where coarser sediments occur. The P. strombus occurrence and densities are determined by both the sediment type and the number of available empty tubes that Phascolion dwells in (Hylleberg 1975). Phascolion strombus is also known to avoid small grain sized sediments, like soft clays, which can clog its apertures and render irrigation impossible (Hylleberg 1975). The type of sediment that was avoided by sipunculans was sediment with high proportion of medium and fine sands. Similar results were obtained in the Barents Sea where sipunculans were more abundant on the muddy sediments and tended to avoid sandy bottoms (Garbul and Anisimova 2012). Our results showed that sipunculan occurrence was explained by the depth factor; however, since the area sampled during this study was a shallow shelf (40-130 m, stations in deeper Beaufort Sea excluded), this correlation seems to be more of a proxy for food availability and sediment type. Similarly, the latitude can be regarded as a proxy for changing sea ice persistence (Frey et al. 2015) and may therefore reflect different food types reaching the sea floor.

Due to their tendency to aggregate and reach high community biomass, some sipunculans (e.g., Golfingia) may become an important food source for higher trophic level fauna. In the Pacific Arctic two important sipunculan consumers have been identified: the walrus (Sheffield et al.
2001; Sheffield and Grebmeier 2009) and crabs (e.g., the snow crab; Divine et al. 2017); however, fish and gastropods can prey on sipunculans as well (Kohn 1975). Sipunculans are a potentially nutritious food item: the mean energy (caloric) content of $G$. margaritacea was reported to be $18.42 \mathrm{MJ} \mathrm{kg}^{-1}$ but can also reach as high a value as $21.47 \mathrm{MJ} \mathrm{kg}^{-1}$, which is similar to the caloric content of amphipods - an important food item for gray whales, but lower than the caloric content of bivalves and polychaetes, which are often preyed upon by walruses (Wilt et al. 2014; Wilt pers. comm.). The Pacific walrus forage in shallow (down to $100 \mathrm{~m}$ ) waters, usually either from nearby sea ice or from land where they haul-out, and although they can feed on a wide array of animals, softerbodied organisms with high fat and caloric contents are preferred (Sheffield and Grebmeier 2009; Jay et al. 2014). Stomach samples are often found to include bivalves, gastropods, and polychaetes, although sipunculans are also among the frequent prey (Sheffield and Grebmeier 2009; Jay et al. 2014). Walruses are highly dependent on the sea ice as resting platforms while foraging far from the shore (Kovacs et al. 2011). Due to the recently observed reduction in the seasonal sea ice cover, walruses may have to change their preferred foraging sites and thus an increased foraging pressure on the preferred bivalve species may be expected (Jay et al. 2011, 2012, 2014), potentially depleting local populations (Coyle et al. 2007). In such an eventuality, sipunculans may play a larger role as a walrus prey item. Similarly, sipunculans are among the favored food prey for the snow crab (Chionoecetes opilio) in the Pacific Arctic, although not the first choice (Divine et al. 2017). Demersal feeding fish are also known to prey on sipunculans. In the Barents Sea the large individuals of Golfingia were found in $20 \%$ of demersal feeding fish stomachs (Garbul and Anisimova 2012) which suggests that demersal feeding fish in the Pacific Arctic Region may also feed extensively on sipunculans.

The role of sipunculans as bioturbators should not be overlooked. Although on the Arctic shelves many species are known to bioturbate the sediment, Golfingia - an active burrower that usually reaches large sizes and creates dense populations-may locally significantly alter the sediment properties through deep reaching bioturbation and bioirrigation. Moreover, sipunculans-if present-can largely dominate the total benthic abundance and biomass on Arctic shelves, and therefore the functioning of the local communities. However, burrowing capacities of P. strombus and $N$. diaphanes that both live in mollusk shells or polychaete tubes are considerably lower, and cannot be considered significant. The species that is known for its significant role in the deep sea ecosystems is the burrower Nephasoma lilljeborgi (Romero-Wetzel 1987; Graf 1989; Shields and Kędra 2009). The complex gallery burrows 
produced by this species, which can reach $30-50 \mathrm{~cm}$ deep in the sediment, and the associated rapid subduction of organic matter are of large importance in the deep sea ecosystems where burrowers are less common than on shelves (Romero-Wetzel 1987; Graf 1989; Shields and Kędra 2009). Although we have not found N. lilljeborgi in this study, and it has not been reported by other authors from the Pacific portion of the Arctic (Murina 1977; Cutler 1994), it is possible that it inhabits deeper portions of the northern Chukchi and Beaufort Seas, and well as the Arctic Basin, as it is an important component of Nordic Seas deep communities (Shields and Kędra 2009; Kędra and Shields 2011). However, more studies are needed in the Pacific sector deep sea to confirm its occurrence and function.

Sipunculans, if present, can significantly influence composition and functioning of the benthic communities. Here, the dominance of sipunculans in total benthic abundance reached up to $8-12 \%$ (but usually was about $1-2 \%)$. In total benthic biomass sipunculans constituted up to $50-85 \%$, and at one third of stations, if sipunculans were found, they constituted more than $10 \%$ of total benthic biomass. The peak of sipunculan dominance was observed between $68^{\circ}$ and $72^{\circ} \mathrm{N}$ and in general tended to increase northwards. Those northern areas are characterized by high deposition processes and are inhabited by diverse benthic communities that include other deposit feeding taxa like tellinid and nuculanid bivalves, and maldanid polychaetes, but also suspension feeding amphipods, and predatory lyssianasids and nepthyds (Grebmeier 2012). The highest benthic (and sipunculan) biomass occurs at the head of Barrow Canyon, where suspension feeding Musculus bivalves and Golfingia are dominant by biomass owing to the large load of organic carbon that transits northward from the Chukchi Sea system, along with high spring primary production in the region (Hill and Cota 2005; Grebmeier 2012). On the other hand, sipunculans were absent in the areas with lower carbon accumulation in the sediments, e.g., in the central Chukchi Sea and north of St. Lawrence Island (Grebmeier et al. 2006), with fast currents and/or sandy bottoms (Chirikov Basin, Bering Strait, parts of the southern Chukchi Sea). In general, areas with high benthic taxa and functional diversity - and high organic matter loads-seem to favor sipunculan mass-occurrence, while areas with low amount of available organic matter and some type of environmental disturbance reduce or eliminate sipunculans from benthic communities.

The low number of sipunculan species found during this study is typical for Arctic locations (Murina 1977) since sipunculan biodiversity is greatest in the tropical and subtropical seas (Cutler 1994). Species, like N. lilljeborgi and Nephasoma abyssorum, which are typical of Arctic deepsea communities (>1000 m, not sampled here; Kędra and Shields 2011) were not found in this study but are likely to inhabit the Arctic basins. Compared to the northern Bering (four species) and Chukchi (five species) Seas, the two species solely found in the Beaufort Sea seem to indicate an underestimation of Beaufort sipunculan species richness. However, this is most likely a result of sampling effort and gear used. The trawling, and generally gear designed to collect epifauna, are not efficient in collecting the infaunal sipunculan species. The van Veen grabs and box corers prove to be more effective in sipunculan collection then dredges (personal observations). This is due to the fact that sipunculans live burrowed in the sediment, but close to the sediment surface where they feed; however, if stressed, they are able to burrow deep and fast. Thus sipunculans are likely to escape dredges and surface collecting gear but it is less likely that they can avoid deep penetration grabs or boxcorers. Grabs are also useful for sampling smaller sized sipunculans, such as e.g., Nephasoma spp. Phascolion strombus is a sipunculan species living on the sediment, in shelters provided by shells and tubes, and its dominance in the dredge samples collected in the Beaufort Sea is not surprising. This means however that more effort, especially quantitative sampling with grabs, is still needed in the Beaufort Sea in order to fully determine the diversity of sipunculans and their distribution patterns. Most likely, all species found in the other Pacific Arctic seas can be expected to be present also in the Beaufort Sea.

The high production (biomass) of sipunculans, as observed in many areas of the Chukchi Sea, has been also reported from other Arctic locations, such as the Svalbard fjords (Kędra and Włodarska-Kowalczuk 2008) and the Barents Sea (Denisenko et al. 2003; Garbul and Anisimova 2012), and the high dominance of sipunculans is a feature commonly observed in many Arctic soft-bottom benthic populations. The abundance of sipunculans, however, varies widely, from quite scattered (single specimens per $\mathrm{m}^{-2}$, e.g., this study) to very dense, about 400 ind. $\mathrm{m}^{-2}$ in the deep Nordic Seas and the Fram Strait (Romero-Wetzel 1987; Graf 1989; Shields and Kędra 2009; Kędra and Murina 2007), to 620 ind. $\mathrm{m}^{-2}$ in the Svalbard fjords (Kędra and Włodarska-Kowalczuk 2008), with the highest abundances observed in our current study (1745 ind. $\mathrm{m}^{-2}$ ). This finding seems to be another typical feature of sipunculan communities globally which, if present, can occur with very high densities (Cutler 1994). On Arctic shelves, the genus that often dominates is Golfingia (Kędra and Włodarska-Kowalczuk 2008; Garbul and Anisimova 2012; this study), which-due to its large sizes-has further implications on the benthic biomass and energy transfer to higher trophic levels. Also P. strombus is a common shelf Arctic species (Murina 1977; Murina and Sorensen 2004; Kędra and Włodarska-Kowalczuk 2008; Garbul and Anisimova 2012; this study). The deep Arctic Ocean, on the other hand, is primarily dominated by species of the 
genus Nephasoma (Murina 1977; Murina and Sorensen 2004; Kędra and Shields 2011) which, due to its burrowing activities, has important implications for organic matter distribution in the sediment and carbon turnover (RomeroWetzel 1987; Graf 1989; Shields and Kędra 2009). Thus, sipunculans, although species poor, should not be overlooked in Arctic ecological studies.

Acknowledgements We thank Drs. Bodil Bluhm and Katrin Iken for providing sipunculan specimens from the Beaufort Sea that were collected through funding provided by the US Department of the Interior, Bureau of Ocean Energy Management, Environmental Studies Program, Washington, DC, under Agreement Nos. M10AC20004 and M12AC00011 and Contract Nos. M11PX00115 and M12PC00001. We thank the personnel of the benthic sorting lab at the Chesapeake Biological Laboratory, including Linton Beaven, Christian Johnson, Arvind Shantharam, Stephanie Soques, Mike Studivan, and Lisa Wilt for undertaking the work that facilitated our determinations of abundance, biomass, and ultimately significance of sipunculan species in the Pacific Arctic. Chirk Chu is thanked for data processing without whom this work would not be possible. We thank P.E. Renaud and two anonymous reviewers for helping to improve a previous version of the manuscript. M. Kędra was supported by Polish National Science Centre Grant No. DEC-2013/08/M/NZ8/00592 and statutory funds of Institute of Oceanology Polish Academy of Sciences. Jacqueline Grebmeier and Lee Cooper were supported in this work by the National Science Foundation Award No. 1204082.

Funding This study was funded by Polish National Science Centre grant no. DEC-013/08/M/NZ8/00592 (work of M. Kędra) and National Science Foundation Award 1204082 (work of J. Grebmeier and L. Cooper). Sampling in the Beaufort Sea was funded by Bureau of Ocean Energy Management, Environmental Studies Program, Washington, DC, under Agreement Nos. M10AC20004 and M12AC00011 and Contract Nos. M11PX00115 and M12PC00001.

\section{Compliance with ethical standards}

Conflict of interest The authors declare that they have no conflict of interest.

Ethical approval All applicable international, national, and/or institutional guidelines for the care and use of animals were followed. This article does not contain any studies with human participants performed by any of the authors.

Open Access This article is distributed under the terms of the Creative Commons Attribution 4.0 International License (http://crea tivecommons.org/licenses/by/4.0/), which permits unrestricted use, distribution, and reproduction in any medium, provided you give appropriate credit to the original author(s) and the source, provide a link to the Creative Commons license, and indicate if changes were made.

\section{References}

Ambrose WG, von Quillfeldt C, Clough LM, Tilney PVR, Tucker T (2005) The sub-ice patterns of abundance based on images from a remotely operated vehicle. Polar Biol 28:784-795

Bates NR, Hansell DA, Moran SB, Codispoti LA (2005) Seasonal and spatial distributions of particulate organic matter (POM) in the Chukchi Sea. Deep Sea Res II 52:3324-3343
Coachman LK, Aagaard K, Tripp RB (1975) Bering strait: the regional physical oceanography. University of Washington Press, Seattle and London

Cooper LW, Larsen IL, Grebmeier JM, Moran SB (2005) Detection of rapid deposition of sea ice-rafted material to the Arctic Ocean benthos using the cosmogenic tracer ${ }^{7} \mathrm{Be}$. Deep Sea Res II 52:3452-3461

Coyle KO, Bluhm B, Konar B, Blanchard A, Highsmith RC (2007) Amphipod prey of gray whales in the northern Bering Sea: comparison of biomass and distribution between the 1980s and 2002-2003. Deep Sea Res II 54:2906-2918

Crane K, Ostrovskiy A (2015) Introduction to the special issue: Russian-American Long-term Census of the Arctic (RUSALCA). Oceanography 28:18-23. doi:10.5670/oceanog. 2015.54

Cutler EB (1994) The Sipuncula. Their systematics, biology, and evolution. Cornell University Press, New York

Denisenko SG, Denisenko NV, Lehtonen KK, Andersin AB, Laine AO (2003) Macrozoobenthos of the Pechora Sea (SE Barents Sea): community structure and spatial distribution in relation to environmental conditions. Mar Ecol Prog Ser 258:109-123

Divine LM, Bluhm B, Mueter F, Iken K (2017) Diet analysis of Alaska Arctic snow crabs (Chionoecetes opilio) using stomach contents and $\delta^{13} \mathrm{C}$ and $\delta^{15} \mathrm{~N}$ stable isotopes. Deep Sea Res II 135:124-136

Dunton KH, Saupe SM, Golikov AN, Schell DM, Schonberg SV (1989) Trophic relationships and isotopic gradients among arctic and subarctic marine fauna. Mar Ecol Prog Ser 56:89-97

Dunton KH, Ashjian C, Campbell RG, Cooper LW, Grebmeier JM, Harvey HR, Konar B, Maidment DM, Trefry JH, Weingartner TJ (2016) Chukchi sea offshore monitoring in drilling area (COMIDA): Hanna Shoal ecosystem study. Final Report. OCS Study BOEM 2016-047. Prepared for the Bureau of Ocean Energy Management, Anchorage, AK. The University of Texas Marine Science Institute, Port Aransas

Fischer W (1925) Die tierwelt der nord- und ostsee. Akademische Verlagsgesellschaft, Leipzig

Frey KE, Moore GWK, Cooper LW, Grebmeier JM (2015) Divergent patterns of recent sea ice cover across the Bering, Chukchi and Beaufort seas of the Pacific Arctic Region. Prog Oceanogr 136:32-49

Garbul EA, Anisimova NA (2012) Some features of the quantitative distribution of sipunculan worms (Sipuncula) in the central and southern Barents Sea. Oceanologia 54:59-74

Gibbs PE (1977) British sipunculans: keys and notes for the identification of the species. Synopses of the British fauna (new series). Academic Press, London

Graf G (1989) Benthic-pelagic coupling in a deep-sea benthic community. Nature 314:437-439

Grall J, Le Loc'h F, Guyonnet B, Riera P (2006) Community structure and food web based on stable isotopes $\left(\delta^{15} \mathrm{~N}\right.$ and $\left.\delta^{13} \mathrm{C}\right)$ analysis of a North Eastern Atlantic maerl bed. J Exp Mar Biol Ecol $338: 1-15$

Grebmeier JM (2012) Shifting patterns of life in the Pacific Arctic and sub-arctic seas. Ann Rev Mar Sci 4:63-78

Grebmeier JM, Cooper LW (1994) A decade of benthic research on the continental shelves of the northern Bering and Chukchi Seas: lessons learned. In: Meehan RH, Sergienko V, Weller G (eds) Bridges of science between North America and the Russian Far East. American Association for the Advancement of Science, Arctic Division, Fairbanks, pp 87-98

Grebmeier JM, Cooper LW (2014a) PacMARS surface sediment parameters, Version 1.0. http://dx.doi.org/10.5065/D6416V3G; PacMARS EOL data archive site http://pacmars.eol.ucar.edu

Grebmeier J, Cooper L (2014b) PacMARS Benthic infaunal parameters dominant fauna (2000-2012), Version 1.0. http://dx.doi. 
org/10.5065/D60C4SVZ; PacMARS EOL data archive site http://pacmars.eol.ucar.edu

Grebmeier J, Cooper L (2014c) PacMARS benthic infaunal parameters (1970-2012), Version 1.0. http://dx.doi.org/10.5065/ D6H70CVR; PacMARS EOL data archive site http://pacmars. eol.ucar.edu

Grebmeier JM, McRoy CP (1989) Pelagic-benthic coupling on the shelf of the northern Bering and Chukchi Seas. III. Benthic food supply and carbon cycling. Mar Ecol Prog Ser 53:79-91

Grebmeier JM, Cooper LW (2016) The Saint Lawrence island polynya: a 25-year evaluation of an analogue for climate change in polar regions. In: Glibert PM, Kana TM (eds) Aquatic nutrient biogeochemistry and microbial ecology: a dual perspective. Springer International Publishing, Switzerland, pp 171-183

Grebmeier JM, Cooper LW, Feder HM, Sirenko BI (2006) Ecosystem dynamics of the Pacific-influenced Northern Bering and Chukchi Seas in the Amerasian Arctic. Prog Oceanogr 71:331-361

Grebmeier JM, Bluhm BA, Cooper LW, Danielson S, Arrigo KR, Blanchard AL, Clarke JT, Day RH, Frey KE, Gradinger RR, Kędra M, Konar B, Kuletz KJ, Lee SH, Lovvorn JR, Norcross BL, Okkonen SR (2015) Ecosystem characteristics and processes facilitating persistent macrobenthic biomass hotspots and associated benthivory in the Pacific Arctic. Prog Oceanogr 136:92-114

Hansen MD (1978) Nahrung und Fressverhalten bei Sedimentfressern dargestellt am Beispiel von Sipunculiden und Holothurien. Helgoländer Meeresun 31:191-221

Hill V, Cota G (2005) Spatial patterns of primary production on the shelf, slope and basin of the Western Arctic in 2002. Deep Sea Res II 52:3344-3354

Hill V, Ardyna M, Lee SH, Varela DE (2017) Decadal trends in phytoplankton production in the Pacific Arctic Region from 1950 to 2012. Deep Sea Res II. doi:10.1016/j.dsr2.2016.12.015

Hirawake T, Shinmyo K, Fujiwara A, Saitoh S (2012) Satellite remote sensing of primary productivity in the Bering and Chukchi Seas using an absorption-based approach. ICES J Mar Sci 69:1194-1204

Hylleberg J (1975) On the ecology of the Sipunculan Phascolion strombi (Montagu). In: Rice ME, Rodorović M (eds) Proceedings of the International Symposium on the Biology of the Sipuncula and Echiura, Belgrade, pp 241-250

Iken K, Bluhm B, Dunton K (2010) Benthic food-web structure under differing water mass properties in the southern Chukchi Sea. Deep-Sea Res II 57:71-85

Jay CV, Marcot BG, Douglas DC (2011) Projected status of the Pacific Walrus (Odobenus rosmarus divergens) in the twentyfirst century. Polar Biol 34:1065-1084

Jay CV, Fischbach AS, Kochnev AA (2012) Walrus areas of use in the Chukchi Sea during sparse sea ice cover. Mar Ecol Prog Ser 468:1-13

Jay CV, Grebmeier JM, Fischbach AS, McDonald TL, Cooper LW, Hornsby F (2014) Pacific Walrus (Odobenus rosmarus divergens) resource selection in the Northern Bering Sea. PLoS ONE 9:e93035

Kędra M, Grebmeier JM (in press) Sipunculan fauna of the northern Bering and Chukchi Seas. In: Boyle MJ, Kawauchi GY (eds) Proceedings of the 2nd International Symposium on the Biology of the Sipuncula. Smithsonian Contributions to the Marine Sciences, Smithsonian Institution Scholarly Press, Washington DC

Kędra M, Murina GV (2007) The sipunculan fauna of Svalbard. Polar Res 26:37-47

Kędra M, Shields MA (2011) On the deep-sea Nephasoma species in the Eastern North Atlantic-a taxonomic guide. Mar Biol Res $7: 43-53$

Kędra M, Włodarska-Kowalczuk M (2008) Distribution and diversity of sipunculan fauna in high Arctic fjords (west Svalbard). Polar Biol 31:1181-1190
Kohn AJ (1975) Predation on Sipunculans. In: Rice ME, Rodorović $M$ (eds) Proccedings of the International Symposium on the Biology of the Sipuncula and Echiura, Belgrade, pp 313-333

Kovacs K, Moore S, Lydersen C, Overland JE (2011) Impacts of changing sea ice conditions on Arctic marine mammals. Mar Biodiv 41:181-194

Lee SH, Joo H-M, Yun MS, Whitledge TE (2012) Recent phytoplankton productivity of the northern Bering Sea during early summer in 2007. Polar Biol 35:83-98

Lowry KE, Pickart RS, Mills MM, Brown ZW, Van Dijken G, Bates NR, Arrigo KR (2015) The influence of winter water on phytoplankton blooms in the Chukchi Sea. Deep Sea Res II 118:53-72

McMahon KW, Ambrose WG, Johnson BJ, Sun MY, Lopez GR, Clough LM, Carroll ML (2006) Benthic community response to ice algae and phytoplankton in Ny Ålesund, Svalbard. Mar Ecol Prog Ser 310:1-14

Moran SB, Kelly RP, Hagstrom K, Smith JN, Grebmeier JM, Cooper LW, Cota GF, Walsh JJ, Bates NR, Hansell DA, Maslowski W, Nelson RP, Mulsow S (2005) Seasonal changes in POC export flux in the Chukchi Sea and implications for water columnbenthic coupling in Arctic shelves. Deep Sea Res II 52:3427-3451

Murina GV (1977) Marine worms of the Arctic and boreal waters of Europe. Works on the fauna of the USSR. Academy of Science USSR, Leningrad

Murina GV (1984) Ecology of sipuncula. Mar Ecol Prog Ser 17:1-7

Murina GV (1985) Sipunculids of the Chukchi Sea. In: Shirshov PP (ed) Ecology of the ocean coastal zone benthic fauna and flora. Academy of Science USSR, Moscow, pp 36-46

Murina GV, Sorensen J (2004) Marine Worms of the Phylum Sipuncula in Faroese waters. Frðdskaparrit 51:280-291

Norcross BL, Apsens SJ, Bell LE, Bluhm BA, Dissen JN, Edenfield LE, Frothingham A, Gray BP, Hardy SM, Holladay BA, Hopcroft RR, Iken KB, Smoot CA, Walker KL, Wood ED (2016) US-Canada transboundary fish and lower trophic communities: abundance, distribution, habitat and community analysis. Draft final Report for BOEM Agreement Number M12AC00011. University of Alaska, Fairbanks

Olgoonik Fairweather LLC (2017) Arctic nearshore impact monitoring in development area (ANIMIDA) III: contaminants, sources, and bioaccumulation. Contract Number M13PC00019. Draft Final Report OCS Study BOEM AK-11-14B

Petrenko D, Pozdnyakov D, Johannessen J, Counillon F, Sychov V (2013) Satellite-derived multi-year trend in primary production in the Arctic Ocean. Int J Remote Sens 34:3903-3937

Pisareva MN, Pickart RS, Iken K, Ershova EA, Grebmeier JM, Cooper LW, Bluhm BA, Nobre C, Hopcroft RR, Hu H, Wand J, Ashjian CJ, Kosobokova KN, Whitledge TE (2015) The relationship between patterns of benthic fauna and zooplankton in the Chukchi Sea and physical forcing. Oceanography 28:68-83

Romero-Wetzel MB (1987) Sipunculans as inhabitants of very deep, narrow burrows in deep-sea sediments. Mar Biol 96:87-91

Sakshaug E (2004) Primary and secondary production in the Arctic seas. In: Stein R, Macdonald RW (eds) The organic carbon cycle in the Arctic Ocean. Springer, New York, pp 81-87

Sheffield G, Grebmeier JM (2009) Pacific walrus (Odobenus rosmarus divergens): differential prey digestion and diet. Mar Mamm Sci 25:761-777

Sheffield G, Fay FH, Feder HM, Kelly BP (2001) Laboratory digestion of prey and interpretation of walrus stomach contents. Mar Mamm Sci 17:310-330

Shields MA, Kędra M (2009) A deep burrowing sipunculan of ecological and geochemical importance. Deep Sea Res I 56:2057-2064 
Stephen AC, Edmonds SJ (1972) The phyla Sipuncula and Echiura. Trustees of the British Museum (Natural History), London

ter Braak CJF, Smilauer P (2002) CANOCO reference manual and CanoDraw for Windows user's guide: software for canonical community ordination (version 4.5). Microcomputer Power, Ithaca

Tremblay JE, Bélanger S, Barber DG, Asplin M, Martin J, Darnis G, Fortier L, Gratton Y, Link H, Archambault P, Sallon A, Michel C, Williams WJ, Philippe B, Gosselin M (2011) Climate forcing multiplies biological productivity in the coastal Arctic Ocean. Geophys Res Lett 38:L18604

Walsh JJ, McRoy CP, Coachman LK, Goering JJ, Nihoul JJ, Whitledge TE, Blackburn TH, Parker PL, Wirick CD, Shuert PG, Grebmeier JM, Springer AM, Tripp RD, Hansell DA, Djenidi S, Deleersnijder E, Henriksen K, Lund BA, Andersen P, Müller-Karger FE, Dean K (1989) Carbon and nitrogen cycling within the Bering/Chukchi Seas: source regions of organic matter affecting AOU demands of the Arctic ocean. Prog Oceanogr 22:277-359

Walter MD (1973) Fresshalten und Darminhaltsuntersuchungen bei Sipunculiden. Helgoländer Meeresun 25:486-494

Weingartner TJ, Aagaard K, Woodgate R, Danielson S, Sasaki Y, Cavalieri D (2005) Circulation on the north central Chukchi Sea shelf. Deep Sea Res II 52:3150-3174
Wesenberg-Lund E (1934) Gephyrans and annelids. The Scoresby sound committee's second east Greenland expedition in 1932 to King Christian IX Land. Medd Grønl 104:1-38

Wesenberg-Lund E (1937) The zoology of east Greenland: Gephyreans. Medd Grønl 121:1-25

Wesenberg-Lund E (1938) The godthaab expedition 1928. Gephyrea. Medd Grønl 79:1-29

Wilt LM, Grebmeier JM, Miller TJ, Cooper LW (2014) Caloric content of Chukchi Sea benthic invertebrates: modeling spatial and environmental variation. Deep Sea Res II 102:97-106

Woodgate RA, Aagaard K, Weingartner TJ (2005a) Monthly temperature, salinity, and transport variability of the Bering Strait throughflow. Geophys Res Lett 32:L04601

Woodgate RA, Aagaard K, Weingartner TJ (2005b) A year in the physical oceanography of the Chukchi Sea: moored measurements from autumn 1990-1991. Deep Sea Res II 52:3116-3149

Woodgate R, Weingartner T, Lindsay R (2012) Observed increases in Bering Strait oceanic fluxes from the Pacific to the Arctic from 2001 to 2011 and their impacts on the Arctic Ocean water column. Geophys Res Lett 39:L24603 